\title{
Did hybridization save the Norfolk Island boobook owl Ninox novaeseelandiae undulata?
}

\author{
Stephen T. Garnett, Penny Olsen, Stuart H.M. Butchart \\ and ARY. A. HoF F M A N
}

\begin{abstract}
The population of the Norfolk Island boobook owl Ninox novaeseelandiae undulata, a nocturnal bird restricted to the Australian territory of Norfolk Island, was reduced to a single female in 1986. Deliberate introduction of two males of its nearest relative, the New Zealand boobook N. n. novaeseelandiae, as a conservation intervention has allowed the taxon to persist on Norfolk Island, albeit in hybrid form. Although declared Extinct in 2000 , a re-examination of this unique situation has concluded there is a strong argument that the taxon should be categorized as Critically Endangered because, on average, approximately half the nuclear genome of the original taxon and all the mitochondrial DNA is conserved in all living owls on the island. This thus represents a special case in which the taxon can be considered to be extant, in hybrid form, even though no pure-bred individuals survive. More generally, we suggest that, in exceptional cases, hybridization may not be a threat to highly threatened species and that guidelines are needed to determine when to consider hybrid populations as extant forms of the original taxon, and when to declare extinction through hybridization.
\end{abstract}

Keywords Extinction, hybridization, IUCN Red List criteria, Ninox novaeseelandiae undulata, Norfolk Island, owl

\section{Introduction}

T ybridization is considered on the IUCN Red List 1 among a suite of stresses brought about by particular threats that can lead to extinction (Salafsky et al., 2008; IUCN, 2010). A total of 15 threatened and 9 Near Threatened bird species are affected by this stress (BirdLife International, 2010). Most instances of damaging hybridization occur in areas where environmental change has removed barriers to interbreeding with native species such

STEPHEN T. GARnETT (Corresponding author) Research Institute for Environment and Livelihoods, Charles Darwin University, Northern Territory 0909, Australia. E-mail stephen.garnett@cdu.edu.au

PENNy Olsen Ecology, Evolution and Genetics, Research School of Biology, The Australian National University, Canberra, Australia

Stuart H.M. Butchart BirdLife International, Cambridge, UK

Ary. A. Hoffmann Bio21 Institute, Department of Genetics, The University of Melbourne, Victoria, Australia

Received 13 February 2011. Revision requested 15 April 2011.

Accepted 27 April 2011. that there is a continuing inflow of genetic material that had previously been impossible, or result from exposure to feral or domesticated populations of related taxa. Examples of taxa deleteriously affected by hybridization include the unassisted range expansion of the African little grebe Tachybaptus ruficollis contributing to the extinction of the Alaotra grebe T. rufolavatus in Madagascar (Hawkins et al., 2000), the Seychelles fody Foudia sechellarum being threatened by hybridization with the introduced Madagascar fody F. madagascariensis (Rocamora et al., 2003) and vegetation clearance in south-east Australia allowing ingress of yellow-throated miner Manorina flavigula into habitat of black-eared miner M. melanotis, leading to widespread hybridization (Clarke et al., 2001).

In many cases habitat change and a scarcity of conspecific partners have allowed incursion of closely related taxa from adjacent areas. Behavioural barriers prove insufficient to prevent interbreeding. Such hybrid offspring may have apparently equal or greater fitness than pure-bred individuals (Grant \& Grant, 1992). Sometimes geographical barriers have been removed when a population of a close relative is established within the range of a species through human agency. Examples of this are the endangered Hawaiian duck Anas wyvilliana, which has hybridized with the introduced mallard Anas platyrhynchos (Browne et al., 1993), and the ruddy duck, which has hybridized with white-headed duck in southern Europe (Muñoz-Fuentes et al., 2007). If at some point all living individuals in the population are hybrids the taxon would be described as Extinct under the IUCN Red List guidelines (IUCN, 2010).

However, hybridization is also a natural process and can be a key component of speciation and adaptation (Grant \& Grant, 2008; Mallet, 2008; Schwenk et al., 2008). Also, under exceptional circumstances, hybridization may be the only means remaining to effect conservation of extremely depleted populations. In such cases it may be appropriate not to declare the taxon Extinct but to consider it as persisting, albeit in a different form, because genes from the threatened species or population are conserved. In this paper we describe the case of the Norfolk Island boobook owl, a taxon whose population declined until only a single female survived.

\section{The case of the Norfolk Island owl}

The Norfolk Island owl Ninox novaeseelandiae undulata was probably once distributed throughout the Australian territory of the $35 \mathrm{~km}^{2}$ Norfolk Island and associated Philip 
Island, in the Pacific Ocean, $767 \mathrm{~km}$ from the nearest land, New Caledonia. However, until recently, and since at least 1909, the owl was largely confined to near Mt Pitt in what is now Norfolk Island National Park.

Extensive clearance for agriculture and felling of large trees destroyed most suitable nest holes on Norfolk Island (Olsen \& Hicks, 1989; Olsen, 1996). Introduced crimson rosellas Platycercus elegans, European starlings Sturnus vulgaris, Polynesian rats Rattus exulans and black rats Rattus rattus and occasionally honeybees Apis mellifera compete for the remaining hollows (Olsen, 1996). Philip Island was totally stripped of its vegetation in the 19th century but is slowly recovering since the removal of pigs and rabbits but it remains unsuitable for owls. As an added stress, in the 1910s many specimens of the owl were collected for museums (Olsen, 1996). A change in forest structure, as a result of weed invasion, may also have reduced the area of habitat available (Olsen et al., 1989). The success of introductions and the associated nest-box programme (which includes rat, starling and crimson rosella control and exclusion) suggests a shortage of hollows was the ultimate cause of population decrease (P.D. Olsen, pers. obs.).

By the 1970 all recent records came from an area of c. $2 \mathrm{~km}^{2}$, most of which was native forest within Norfolk Island National Park or exotic plantations with a relatively clear understorey. Weed-infested native forest with a dense understorey was apparently avoided (Olsen et al., 1989). The subspecies was first recognized as threatened in the 1960 s, when visiting biologists neither heard nor saw owls. In 1973, 1978 and 1985, reports of calls were published, a survey was conducted and local residents continued to hear at least one bird. A thorough survey in October 1986, repeated in 1987, found the sole surviving bird, a female, in the area from which many of the calls had been heard (Olsen et al., 1989).

In 1988 two male N. n. novaeseelandiae from New Zealand, the closest relative of $N . n$. undulata, were introduced to the island. One of these birds survived, bred with the female and produced two broods of two offspring each. Of these, a son and daughter produced at least 17 , and probably 21 , offspring. The sole $N$. $n$. undulata female was last seen in late 1996. The male survived at least a further 2 years and bred with his granddaughter, producing four offspring.

Between December 1989 and December 1999, 28 N. $n$. undulata/novaeseelandiae hybrid nestlings were banded (Olsen, 1996; Norman et al., 1998; P.D. Olsen \& R. Ward, pers. comm.) and 24 have been banded since. In recent years chicks have been banded but monitoring of adults has been less thorough, so that parentage is not always known (bands are extremely hard to see given the owls' short, feathered tarsi and the thick forest). Although the breeding rate has declined, possibly through inbreeding depression or an increased genetic load, the population has persisted to 2010. Owls are heard calling at several locations across the island, although the exact number of individuals is unknown.

With only two founders, the inbreeding coefficient $(F)$, which measures the probability that two alleles are identical by descent and varies between o (no inbreeding) and 1 (completely inbred, all alleles identical by descent), is likely to be high in this population. Offspring were produced from a mating between the son and one of the daughters of the original hybrid cross $(F=0.25)$. In the next generation offspring were produced from a mating between the male and his granddaughter produced from the sib mating $(\mathrm{F}=0.125 \times$ 1.25 or 0.156 , to account for the fact that the mother and father of the granddaughter were already inbred) as well as between matings among grandoffspring which shared the same parents and grandparents $(\mathrm{F}=0.375$ given two successive generations of sib mating). In this generation the cumulative inbreeding coefficient in this population is therefore a weighted average of the $16-19 \%$ of offspring from the parent-granddaughter mating and the $81-84 \%$ of offspring produced from the grandoffspring crosses (i.e. $\mathrm{F}>0.3$ ), which will increase further in later generations from additional matings among relatives.

Despite the success of this programme in retaining a functional population of boobook owls on Norfolk Island, the subspecies was declared Extinct in 2000 (Garnett \& Crowley, 2000) on the basis that hybridization is considered a threatening process in the IUCN Red List system and, logically, a taxon that consists solely of hybrid-derived individuals must be extinct.

\section{Discussion}

There are two reasons why the Norfolk Island owl represents an exception to extinction by hybridization. Firstly, only males were introduced. Thus all mitochondrial DNA derives from the single female, representing the results of many thousands of years of mtDNA evolution under Norfolk Island conditions. This contrasts with standard hybridization in which interbreeding occurs with members of both sexes, effectively swamping the mtDNA genes of the threatened entity. Secondly, the hybridization derived from a single introduction that has not been repeated, whereas hybridization as a threat is usually an ongoing process leading to progressively fewer alleles of the original entity being retained in the population.

By these arguments, therefore, the Norfolk Island owl should be considered extant as a hybrid form. Rather than Extinct, the taxon will be listed in the forthcoming Action Plan for Australian Birds 2010 (Garnett et al., 2011) as Critically Endangered under the Red List criterion D, because its population numbers fewer than 50 mature individuals. It has persisted after the population was reduced to the absolute minimum for a taxon, the single individual. More generally, in cases where only hybrid 
individuals remain, it could be argued that hybridization does not cause extinction of ancestral genes if the hybridization has ceased, is unlikely to recur, and is by individuals of a single sex.

We also recommend that the level of hybridization that could be considered acceptable for the population to remain a target for conservation be constrained such that c. $50 \%$ of the ancestral genes must derive from the original taxon. This is the case for the Norfolk Island owl, where the extant population has two sources. One source consists of the $16-19 \%$ of the population derived from the mating between the New Zealand male and granddaughter of the hybridization event: even though the male mated with his granddaughter he was still the only introduced individual contributing to the gene pool. For this component of the population the expected frequency of Norfolk Island alleles is 0.25 . For the other estimated $81-84 \%$ of the population derived from matings between sibs the expected frequency of Norfolk Island alleles is 0.5. Therefore, on average for autosomal loci $45-46 \%$ of the alleles are expected to be from the ancestral Norfolk Island population. The equivalent figure for mitochondrial DNA loci is $100 \%$.

These estimates assume neutrality of the alleles, whereas any locally adapted Norfolk Island alleles that may define the uniqueness of the taxon would be expected to increase in frequency. On the other hand, under genetic drift, a substantial fraction of the neutral alleles from the original Norfolk Island population (54-55\%) may eventually be lost from the population, particularly if the population size remains small. Even so, until such time as alleles become fixed through drift, many alleles unique to the Norfolk Island population will be maintained in the hybrid population. Because several offspring were produced from the original mating between this female and the introduced male, both of the alleles from the surviving female may persist in the population until they are lost via genetic drift.

Genetic rescue efforts of threatened populations to decrease genetic load focus on repeated introductions of a few individuals (Hedrick \& Fredrickson, 2010). This strategy preserves alleles that are characteristic of the threatened taxon. Over time alleles preserved from the ancestral species should increase in frequency in the hybrid population if they are favoured through natural selection as populations become locally adapted (Verhoeven et al., 2011). This selection process ensures that the uniqueness of a taxon is maintained despite hybridization; for instance, in hybridizing plants and fish dispersed along environmental gradients, species characteristics are maintained at the ends of the gradient, reflecting the effects of local selection in generating adaptive differentiation (Shepherd \& Raymond, 2010; Tobler \& Carson, 2010).

However, this does highlight a broader problem for the way in which the IUCN Red List deals with hybridization. Hybridization is relatively common in bird species; it has been detected in 895 of 9,672 species and 15 of 23 orders (Grant \& Grant, 1992). That is, c. 1 in 10 avian species are known to hybridize, and such hybrids are often fertile and, under some environmental conditions, exhibit higher fitness than the parent species. Among subspecies the issue of hybridization is even more fraught, particularly in hybrid zones where intergrading traits are the norm rather than the exception. The Norfolk Island owl is different only because it was isolated on an island while phenotypic differentiation occurred. Currently the IUCN Red List guidelines (IUCN Standards and Petitions Subcommittee, 2010) provide no guidance on the circumstances under which hybridization should be considered as a threatening process and when it may be considered natural, even desirable.

While some argue that each case of hybridization as a threatening process should be considered on its merits (Genovart, 2009), IUCN guidance would be helpful given that hybridization is likely to be an increasing issue as populations are depleted, habitats altered and species transported around the world (Olsen \& Olsen, 1985; Ellstrand et al., 2010; Johnson et al., 2010). Hybridization can cause loss of the unique genetic constitution of taxa (Rhymer \& Simberloff, 1996; Allendorf et al., 2001) but there needs to be a discussion about the circumstances under which it ceases to be an undesirable process (Ellstrand et al., 2010). For instance, some argue that hybrids should be considered acceptable if ecological function is maintained (Daniels \& Corbett, 2002). In the case discussed here it may be better ecologically, and economically and socially, to have hybrid-derived owls than no owls at all: the story of the owl is told to tourists and is a source of pride to many islanders.

The legal status of hybrids is also unclear under most legislation designed to protect threatened species. The Norfolk Island owl, described as N. n. undulata, is listed as Endangered under the Environment Protection and Biodiversity Conservation Act 1999 but the legal identity of the owls currently on Norfolk Island has never been tested in court and hybridization is mentioned in the Act only with respect to artificially propagated plants. Similarly, the status of hybrids under the US Endangered Species Act is unclear and hybridization is not mentioned. While the definition of species includes subspecies and even distinct populations, a legal determination could result in no protection for hybrids with even a low proportion of foreign genes but much higher levels of protection for pure taxa (Fitzpatrick et al., 2010), if indeed it is possible to identify such entities unequivocally where similar taxa abut or are sympatric. At least one can be reasonably sure of the genetic make-up of owls on isolated Norfolk Island where natural immigration of owls is unlikely. On areas unprotected by natural barriers, genetic overlap between threatened and non-threatened taxa could be even greater than that currently experienced by the owls. In 
the meantime, to quote Levin (2002) in relation to whether governments should protect so-called contaminated taxa: 'Hybridization should be promoted when it is necessary to maintain deteriorating populations, and it should be prevented when it threatens rare species'.

\section{Acknowledgements}

Thanks to David Priddel of the New South Wales National Park Service for resuscitating this issue. This work was supported by Australian Research Council Grants LP0990395 (Increasing the effectiveness of Australian threatened bird conservation) and Laureate Fellowship grant FL100100066.

\section{References}

Allendorf, F.W., Leary, R.F., Spruell, P. \& Wenburg, J.K. (2001) The problems with hybrids: setting conservation guidelines. Trends in Ecology \& Evolution, 16, 613-622.

BirdLife International (2010) 2010 IUCN Red List Assessments for the World's Birds. Http://www.birdlife.org/datazone/species [accessed 27 January 2011].

Browne, R.A., Griffin, C.R., Chang, P.R., Hubley, M. \& Martin, E. (1993) Genetic divergence among populations of the Hawaiian duck, Laysan duck, and mallard. Auk, 110, 49-56.

Clarke, R.H., Gordon, I.R. \& Clarke, M.F. (2001) Intraspecific phenotypic variability in the black-eared miner (Manorina melanotis); human-facilitated introgression and the consequences for an endangered taxon. Biological Conservation, 99, 145-155.

Daniels, M.J. \& Corbett, L. (2002) Redefining introgressed protected mammals: when is a wildcat a wild cat and a dingo a wild dog? Wildlife Research, 30, 213-218.

Ellstrand, N.C., Biggs, D., Kaus, A., Lubinsky, P., McDade, L.A., Preston, K. et al. (2010) Got hybridization? A multidisciplinary approach for informing science policy. BioScience, 60, 384-388.

Fitzpatrick, B.M., Johnson, J.R., Kump, D.K., Smith, J.J., Voss, S.R. \& ShAFFER, H.B. (2010) Rapid spread of invasive genes into a threatened native species. Proceedings of the National Academy of Sciences of the USA, 107, 3606-3610.

Garnett, S.T. \& Crowley, G.M. (2000) The Action Plan for Australian Birds 200o. Environment Australia, Canberra, Australia.

Garnett, S.T., Szabo, J.K. \& Dutson, G. (2011) The Action Plan for Australian Birds 2010. CSIRO, Melbourne, Australia.

Genovart, M. (2009) Natural hybridization and conservation. Biodiversity and Conservation, 18, 1435-1439.

Grant, P.R. \& Grant, B.R. (1992) Hybridization of bird species. Science, 256, 193-197.

Grant, B.R. \& Grant, P.R. (2008) Fission and fusion of Darwin's finch populations. Philosophical Transactions of the Royal Society B: Biological Sciences, 363, 2821-2829.

Hawkins, F., Andriamasimanana, R., Seing, S.T. \& Rabeony, Z. (2000) The sad story of Alaotra grebe Tachybaptus rufolavatus. Bulletin of the African Bird Club, 7, 115-117.

Hedrick, P.W. \& Fredrickson, R. (2010) Genetic rescue guidelines with examples from Mexican wolves and Florida panthers. Conservation Genetics, 11, 616-626.

IUCN (2010) Threats Classification Scheme (Version 3.o). Http:// www.iucnredlist.org/technical-documents/classification-schemes/ threats-classification-scheme-ver3 [accessed 27 December 2010].
IUCN Standards and Petitions Subcommittee (2010) Guidelines for Using the IUCN Red List Categories and Criteria. Version 8.o. Http://intranet.iucn.org/webfiles/doc/SSC/RedList/RedList Guidelines.pdf [accessed 27 December 2010].

Johnson, W.E., Onorato, D.P., Roelke, M.E., Land, E.D., Cunningham, M., Belden, R.C. et al. (2010) Genetic restoration of the Florida panther. Science, 329, 1641-1645.

LEVIN, D. (2002) Hybridisation and extinction: in protecting rare species, conservationists should consider the dangers of interbreeding, which compound the more well-known threats to wildlife. American Scientist, 90, 254-261.

Mallet, J. (2008) Hybridization, ecological races and the nature of species: empirical evidence for the ease of speciation. Philosophical Transactions of the Royal Society B: Biological Sciences, 363, 2971-2986.

Muñoz-Fuentes, V., Vilá, C., Green, A.J., Negro, J.J. \& Sorenson, M.D. (2007) Hybridization between white-headed ducks and introduced ruddy ducks in Spain. Molecular Ecology, $16,629-638$.

Norman, J.A., Olsen, P.D. \& Christidis, L. (1998) Molecular genetics confirms taxonomic affinities of the endangered Norfolk Island boobook Ninox novaeseelandiae undulata. Biological Conservation, 86, 33-36.

Olsen, P.D. (1996) Re-establishment of an endangered subspecies: the Norfolk Island boobook owl. Bird Conservation International, $6,63-80$.

Olsen, P.D. \& Hicks, J. (1989) The very last of the Norfolk Island boobook. Geo, 11, 70-77.

Olsen, P.D., Mooney, N.J. \& Olsen, J. (1989) Status and conservation of the Norfolk Island boobook Ninox novaeseelandiae undulata. In Raptors in the Modern World (eds B.U. Meyburg \& R.D. Chancellor), pp. 123-129. WWGBP, Berlin, Germany.

Olsen, P.D. \& OlSEN, J. (1985) A natural hybridisation of the brown goshawk Accipiter fasciatus (Vigors \& Horsfield) and grey goshawk Accipiter novaehollandiae (Gmelin) in Australia, and a comparison of the two species. Emu, 85, 250-257.

Rhymer, J.M. \& Simberloff, D. (1996) Extinction by hybridization and introgression. Annual Review of Ecology and Systematics, 27, 83-109.

Rocamora, G., Feare, C.J., Skerret t, A., A thanase, M. \& Greig, E. (2003) The breeding avifauna of Cosmoledo Atoll (Seychelles) with special reference to seabirds: conservation status and international importance. Bird Conservation International, 13, 151-174.

Salafsky, N., S alzer, D., S t a t tersfield, A.J., Hilton-T aylor, C., Neugarten, R., Butchart, S.H.M. et al. (2008) A standard lexicon for biodiversity conservation: unified classifications of threats and actions. Conservation Biology, 22, 897-911.

Schwenk, K., Brede, N. \& Streit, B. (2008) Introduction: extent, processes and evolutionary impact of interspecific hybridization in animals. Philosophical Transactions of the Royal Society B: Biological Sciences, 363, 2805-2811.

Shepherd, M. \& Raymond, C. (2010) Species differentiation and gene flow in blackbutts (genus Eucalyptus subgenus Eucalyptus section Pseudophloius). Conservation Genetics, 11, 1965-1978.

Tobler, M. \& CArson, E.W. (2010) Environmental variation, hybridization, and phenotypic diversification in Cuatro Cienegas pupfishes. Journal of Evolutionary Biology, 23, 1475-1489.

Verhoeven, K.J.F., Macel, M., Wolfe, L.M. \& Biere, A. (2011) Population admixture, biological invasions and the balance between local adaptation and inbreeding depression. Proceedings of the Royal Society of London B: Biological Sciences, 278, 2-8. 


\section{Biographical sketches}

Stephen Garnet t coordinates Birds Australia's Threatened Species Committee, which advises BirdLife International on the status of Australia's birds. Penny Olsen is a raptor biologist and wildlife author. She was responsible for the owl reintroduction programme on
Norfolk Island. Stuart Butchart coordinates BirdLife International's scientific research to underpin the setting of conservation priorities, including overseeing the process of assessing all the world's birds for the IUCN Red List. ARy Hoffmann assesses the ability of animals and plants to adapt to climate change through evolution and plasticity. 